\title{
Angles
}

New Perspectives on the Anglophone World

$8 \mid 2019$

Neoliberalism in the Anglophone World

\section{Post-2008 Films: The Financial Crisis in Fictions and Documentaries}

Juliette Feyel and Clémence Fourton

\section{(2) OpenEdition}

1 Journals

\section{Electronic version}

URL: https://journals.openedition.org/angles/640

DOI: 10.4000/angles.640

ISSN: 2274-2042

\section{Publisher}

Société des Anglicistes de l'Enseignement Supérieur

\section{Electronic reference}

Juliette Feyel and Clémence Fourton, "Post-2008 Films: The Financial Crisis in Fictions and

Documentaries", Angles [Online], 8| 2019, Online since 01 April 2019, connection on 06 June 2022.

URL: http://journals.openedition.org/angles/640 ; DOI: https://doi.org/10.4000/angles.640

This text was automatically generated on 6 June 2022.

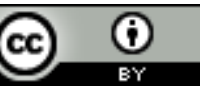

Angles est mise à disposition selon les termes de la Licence Creative Commons Attribution 4.0 International. 


\title{
Post-2008 Films: The Financial Crisis in Fictions and Documentaries
}

\author{
Juliette Feyel and Clémence Fourton
}

1 A crisis is a condition of high instability, capable of generating fundamental changes. To quote Jessop, "[in] short, crises are potentially path-shaping moments." (Jessop 2004: 167). They may appear when the economic and ideological features of a system reach a point of contradiction, eventually causing it to break down (Hall and Massey 2010). As such, the 2008 crunch provides a crucial example, clearly revealing the defining features of neoliberal capitalism.

Neoliberalism has been defined by David Harvey as "a political project to re-establish the conditions for capital accumulation and to restore the power of economic elites" (Harvey 2005: 19). Andrew Gamble (2001), for his part, has insisted on the multiplicity of political forms that neoliberalism has taken around the world. Whether they insist on its unity or its multiplicity, Harvey and Gamble identify similar defining features when it comes to describing the workings of neoliberalism. It is indeed a variety of capitalism characterized by the retrenchment of state-provided social services; the key role played by the state in creating possibilities for private capital accumulation; economic and labour market deregulation; the centrality of finance in the world economy and the use of economic crises in developing countries to advance the interests of globalised capital.

These core neoliberal traits feature prominently in the cinematic representations of the 2008 global financial crisis. The crash led to the production of a substantial number of films which focus on the elements which triggered the crisis, the critical moment itself, and its political and social consequences.

4 Eight such films -4 fictions and 4 documentaries - will be the object of this study: the fiction films Wall Street: Money Never Sleeps (2010), directed by Oliver Stone; Margin Call (2011), by J. C. Chandor; Too Big to Fail (2011), by Curtis Hanson; The Big Short (2015), by Adam McKay; and the documentary films Capitalism, A Love Story (2009), by Michael Moore; Global Financial Meltdown (2010), by Terence McKenna; Inside Job (2010), by Charles Ferguson; and Overdose, the Next Financial Crisis (2010), by Martin Borgs. Films 
that did not concentrate on the moment of the financial crunch were discarded, such as Up in the Air (2009), by Jason Reitman, The Girlfriend Experience (2009), by Steven Soderbergh, and The Other Guys (2010), by Adam McKay.

5 Our corpus brings together popular films, as our aim is to assess the aesthetic and political parti pris of the cinematic representations of the crisis that circulated in the aftermath of the crash. Oliver Stone's 2010 rendition of Wall Street and Adam McKay's 2015 financial robbery tale are the two biggest commercial successes in our corpus: both grossed over $\$ 130$ million worldwide. J. C. Chandor and Michael Moore's takes on the crisis respectively grossed 19 and 17 million dollars worldwide, mostly in the United States, and Charles Ferguson's Oscar-winning documentary grossed around \$8 million. Finally, Curtis Hanson, Terence McKenna and Martin Borgs' productions were all created for television. Hanson's film was made for and broadcast on HBO, an American cable channel, and was nominated for several Golden Globes and Emmy Awards; McKenna's fared well on YouTube (2 million views at the time of writing) and Borg's, although admittedly less widely broadcast, appeared on television around the world.

6 It is therefore fair to assume that these films played a significant part in shaping popular representations of the crisis. Colin Hay brought to the fore the importance of discourse in establishing dominant representations of crises and legitimizing certain forms of strategies when it comes to dealing with such situations (Hay 2001). Building on similar theoretical bases, which amount to rejecting a sharp divide between the cultural and the material, Jessop argued for materially-grounded critical semiotic analysis (Jessop 2004, 2010). In other words, when a crisis occurs, signs - whether in political speeches or in cultural products - matter and play a prominent part in defining the nature and significance of the crisis, as well as what might follow in its wake (Jessop 2004: 167). In the case of the 2008 crisis, Castree (2010) has highlighted the competition between antagonistic interpretations of the crisis, ranging from blaming corrupt and greedy bankers to accusing the Anglo-Saxon neoliberal system itself. As a result, our analysis focuses on the cultural political economy of the 2008 crisis, by offering a critical semiotic analysis of the representation of the crash in fictions and documentaries. We will first present a summary of the films, before proposing a structural comparison of the films, isolating their common features in terms of tropes, characterization and narrative strategy. Thirdly, we will offer and apply a framework assessing the extent to which these films give viewers a critical representation of neoliberalism.

\section{Corpus}

7 Our corpus includes 4 North American fiction films and 4 documentaries. They all delve into the mechanisms of neoliberal capitalism that played a role in the 2008 financial crash. However, in fictions, the crisis is granted varying degrees of importance. In Wall Street: Money Never Sleeps, released in 2010 as a sequel to Stone's 1987 Wall Street, the crisis mainly constitutes the background of a family story. The plot of the 2010 movie is set in 2008-2009, and the protagonist, Jacob Moore (Shia LaBeouf), is a trader for an investment bank affected by the financial crisis. However, the film mainly focuses on the relationship between Jacob, his fiancée Winnie (Carey Mulligan), and her father Gordon Gekko (Michael Douglas). Gekko is involved in illegal financial activities, while 
his estranged daughter runs an online newspaper specialized in investigative journalism. The two men develop a form of partnership in which Gekko provides Moore with information about Wall Street in exchange for news about Winnie.

Conversely, Margin Call centers on the last 24 hours before the crash, making the crash the main dramatic element of the film. The plot focuses on the actions of the executives of a fictional investment bank as they realize a financial crisis is about to occur. Within a few hours, all the senior partners of the firm, played by Kevin Spacey, Paul Bettany, Jeremy Irons and Demi Moore, meet to decide on whether to use their insight to make a profit at the expense of their usual trading partners. While the upcoming crisis is never named, its mechanisms are that of the 2008 financial crisis.

Similarly, Too Big to Fail, directed by Curtis Hanson, focuses on a limited timespan around the crisis. It scrutinizes the actions of Henry Paulson (William Hurt), the American Treasury Secretary, and of Ben Bernanke (Paul Giamatti), the chairman of the US Federal Reserve, between August and October 2008. The two men were at the core of the moves made by the American government to try to circumvent the effects of the collapse of Lehman Brothers.

The most recent fiction selected for our corpus, The Big Short (2015), directed by Adam McKay, pictures not just the days, but the years that preceded the crash. Based on a true story, the plot revolves around a group of traders played by Ryan Gosling and Steve Carell - among others - who, having anticipated the crisis before everyone else, make a huge profit by betting against Collateralized Debt Obligations (CDOs), the financial products at the heart of the bubble.

11 The 4 documentaries of our corpus were, for their part, produced in the immediate aftermath of the crisis - Michael Moore's film was released in 2009 and the other three in 2010. While they all endeavor to explain the crisis, the scope of their analysis varies in terms of scale, chronology and depth. In Capitalism: A Love Story, Moore first focuses on the devastating effects of the explosion of the housing bubble, in particular in the fields of housing and employment, as he goes back to his home city of Flint, Michigan a city already featured in his 1989 documentary film Roger \& Me, which propelled Moore to worldwide attention. In the second part of the film, he analyses the responsibility of political and economic players for the crash and offers alternatives to neoliberal capitalism.

Inside Job, directed by Charles Ferguson, depicts the financial and political mechanisms that led to the crisis. The film offers a genealogy of the crisis, providing a short history of financial deregulation. It then tackles the intricate workings of the financial bubble and the political reactions to the crash. The role of intellectuals in the hegemony of neoliberal ideology is also addressed. Lastly, the film evokes the lack of decisive action on the part of the Obama administration as to regulation.

Overdose: the Next Financial Crisis, by Swedish director Martin Borgs, focuses on the financial mechanisms of the crash and of the bank bailout, insisting on the role of the American government's decisions.

Global Financial Meltdown, directed by Canadian director Terence McKenna, comprises four episodes, entitled "After the Fall", "Paying the Price", "A Global Tsunami" and "The Men who Crashed the World". They focus respectively on the various incarnations of the housing bubble around the world, social movements relating to the crisis, the 
domino effect triggered by the bankruptcy of Bern Sterns, a major bank, and the attitude of political leaders towards the regulation of financial capitalism.

\section{Post-2008 films}

These summaries show that these films belong to the sub-genre labelled "post-2008 films" (Kinkle and Toscano 2011: 42). As such, they share common partis pris concerning the representation of the crisis.

\section{Stereotypical representations of finance}

16 First of all, they all resort to stereotypical representations of the world of finance. The news and file footage used in documentaries have their fictional counterparts: both types of films favor a handful of situations when it comes to representing financial activities. With vertiginous speed, directors juxtapose simultaneous phone-calls, graphs, and figures. The editing conveys the feeling that information and money travel fast between interchangeable open spaces located all over the world. Before the crisis, traders are shown going in and out of elegant skyscrapers. In fictions, they are repeatedly placed in casinos, bars, and strip-clubs, The Big Short being a case in point. In documentaries, if such images are not featured as such, the dissolute nightlife of multimillionaire bonus-earning traders is alluded to. When the crisis hits, traders are invariably shown burying their faces in their hands, and, once they have been laid off, walking out of their offices carrying a cardboard box containing their personal belongings. Capitalism: A Love Story, when describing the events of September 15, 2008, displays a large collection of such images taken from the news, while the opening sequence of Margin Call is a fictional rendition of such a scene.

\section{The evil banker}

17 More specifically, the films in our corpus re-use and develop the stock character of the evil investment banker. In documentaries, it is Dick Fuld, the CEO of Lehman Brothers at the start of the crisis, who is presented as the epitome of ruthless, greedy traders. Meltdown even offers a short biography of Fuld, presenting him as no less than a tyrant: "His word was law, his judgment never to be questioned." In fictions, this trope predates the 2008 crisis: it is already embodied by Gordon Gekko in the 1987 instalment of Wall Street, and by Patrick Bateman (Christian Bale) in American Psycho (2000), directed by Mary Harron. This stock character is typically cynical, as is John Tuld (Jeremy Irons) in Margin Call, whose name echoes Fuld's. Smug and distant, Tuld embodies the archetype of the ruthless financier, deciding to dump toxic assets before the word spreads that they are worthless, ordering massive layoffs and sacrificing his closest collaborators.

However, the fictions of our corpus add a new dimension to the trope. In The Big Short, Michael Burry (Christian Bale) is presented as a mathematical genius displaying characteristics of the autistic spectrum, while Mark Baum (Steve Carell) has intimacy and communication difficulties. In Margin Call, Peter Sullivan (Zachary Quinto), the young analyst who crunches the numbers and figures out the extent of the financial quagmire to come, actually has a background in... rocket science. The fictional 
representations of traders of the 2000s have thus added new features to the original trope, by picturing some as asocial scientific geniuses.

\section{“In plain English"}

19 Given the subject matter of the films, they all deal with a high level of financial complexity. The technicalities of financial activities and the explanations pertaining to them are at the core of the films, including in film fictions. In documentaries, filmmakers can use visual resources, such as graphs and animations, to illustrate their point without fear of interrupting the development of the plot. Inside Job features brightly coloured cartoons to make technical information more accessible. In fictions, directors resort to didactic ploys, which aim at making the explanations blend in with the diegesis. In The Big Short, the financial products are symbolized by bricks taken from the game of Jenga and labelled from AAA to B. Explanations may thus arise over the course of a conversation. In Too Big To Fail and Margin Call, a dumb character, or a character playing dumb, triggers the didactic sequences. In the first case, a member of the staff of the Treasury Secretary needs explanations, allowing the viewer to benefit from clarifications "in plain English." In the second case, CEO John Tuld asks rocket scientist Peter Sullivan to explain to him what is going on and insists on wanting to be talked to as one would to an infant, or even an animal. This dialogue also tends to show that powerful shareholders may be perfectly fine about not understanding the technical aspects of their own financial activities, as long as these are profitable.

In addition to these devices which are specific to either fictions or documentaries, both categories of films use analogies in their attempts at rendering financial jargon accessible. The drug metaphor is spun throughout Overdose, while The Big Short pictures a cooking analogy presented by celebrity chef Anthony Bourdain in his restaurant's kitchen. Such devices contribute to arming the viewer with technical knowledge about the workings of the financial system. These explanations, which are concerned with the specifics of the 2008 crisis, are articulated with a more general point about the historical status of this particular crash.

\section{One crisis among others}

21 Taking a bird's eye view of the history of capitalism, the directors place the 2008 financial crash in perspective. If they all insist on its seriousness, they also tend to depict it as one crisis among others. The crisis appears as the repetition of previous crashes, a perspective best exemplified in Margin Call when, in order to convince the disenchanted trader (Kevin Spacey) that they have no responsibility in the present cash, John Tuld (Jeremy Irons) proceeds to naming previous crises. While the sun sets over Manhattan in the background, representing the eternal cycle of death and rebirth, the viewer thus takes in the long list of previous financial crises: 1637, 1797, 1819, 1837, 1857, 1884, 1901, 1907, 1929, 1937, 1974, 1987, 1992, 1997, and 2000. Put in such perspective, the 2008 crisis appears as no more than a periodical occurrence, unimportant in the grand scheme of things.

In the list of financial crises, 1929 holds a special position, however. Black Thursday is referenced in most documentaries through archival footage. In Meltdown, images of 1929 Wall Street are paralleled with shots of contemporary New York. In Too Big To Fail, 
1929 is conjured up when the relevance of bailing out collapsing banks is discussed. This recurrent comparison hints at potential dramatic political consequences, as the Great Depression is strongly associated in collective memory with the rise of fascism and World War II. But the 2008 crash is also presented as the dress rehearsal of the next, even more serious crisis which is to come. This is stated explicitly in both Overdose and Meltdown. While the subtitle of the latter is simply "the next financial crisis," the former concludes on the following ominous statement: "The world has to start planning for the next crisis even as we realize that this one is not over yet." Similarly, The Big Short closes on the suggestion that speculation has resumed and that the next financial bubble is already growing.

\section{Thrillers and whodunits}

The last common feature concerns the generic divide between fictions and documentaries when it comes to narrative strategies, that is to say the point of view which adopted and the order in which events are presented (Genette 1972). Two strategies at play borrow elements from other cinematic genres: while the fictions of our corpus draw on the structure of thrillers, the documentaries use that of whodunits.

Fictions appear to favor a chronological order. Keeping up with an anxious tempo, the viewer - already aware of how the story will end - is told of how the last pre-crisis months, days if not hours were spent by bankers before an infernal domino effect spread a disease of their own making. Documentaries, on the other hand, begin with establishing that the crisis was a worldwide cataclysm, before moving on to ask: "how did we get here?" It is the film-maker's role to disentangle facts and unveil the causes of - and, more importantly, the responsibilities for - the crisis. The device is that of crime stories, since viewers are made to follow an investigator from the crime scene to the modus operandi, motives, and final exposure of the criminals.

\section{Crisis and Critique}

While it is clear that cinematic representations of the crisis share a number of common features creating a specific sub-genre, the generic divide between fictions and documentaries remains significant when analyzing the critical dimension of these films. We will argue that their critical power depends on two elements: firstly, the amount of information provided in the films matters; more specifically, their ability to picture and explain several of the distinctive features of neoliberalism involved in the 2008 crisis. Secondly, their critical value is also determined by the ability and willingness of the films to entice viewers into anti-capitalist action. While assessing the specifics of the reception of each film is beyond the scope of this article, we can say whether they present alternatives to neoliberalism, and whether they feature critical voices.

Taking into consideration both the complexity of the depiction of the 2008 neoliberal crisis and the space granted to anti-capitalist voices, we produced the following classification, with films ranging from least to most critical. When assessed against such criteria, fictions prove less critical than documentaries in our corpus. 


\section{Wall Street: Money Never Sleeps} tethered to 2008 to provide the context for the sequel of Oliver Stone's 1987 film, Wall Street. The sequel opens on Gordon Gekko's release from prison after eight years behind bars. The stock exchange, which was a recurrent image in the 1987 film, has given way to another location, the building of the Federal Reserve. The housing bubble, which led to the crisis, is alluded to through the character of Jacob Moore's mother, who gave up nursing for real estate. Finally, the film exposes the Machiavellian stratagems and fake rumors circulated by firms to bring down their competitors, leading in the final instance to the necessary bailout of a prominent bank. This sequel offers a less glamorous portrait of bankers than the $1987 \mathrm{film}$, avoiding what could be called a "Gekko effect." The charismatic and obnoxious Gordon Gekko (Michael Douglas) in the first Wall Street film made such an impression on the audience that, in spite of Stone's professed efforts to portray him as unpleasant, the character inspired numerous young people to work in finance (Corliss 2010). Played by the same actor, an older Michael Douglas, Gekko now appears as an antihero who has lost his luster and tries in vain to warn people against the coming catastrophe, while being desperate to mend his relationship with his daughter.

Yet, Stone's endeavor to account for the present-day financial situation centers on the illegal practice of certain corrupted firms, without delving much into the complex causes of the crunch. From a didactic point of view, this film has the narrowest scope of our corpus, given that the plot suggests that Lehman Brothers fell because of rumors started by a rival firm.

Moreover, the storyline mainly revolves around a personal vendetta and family melodrama with a happy ending (Figure 1). Gekko ultimately finds redemption by investing the money he had stolen in the project his daughter Winnie wanted to support. He is then able to obtain both his daughter's pardon and the right to see his grandchild. According to Jeff Kinkle and Alberto Toscano, this conclusion testifies "to a world whose imagination is stripped of collectivity and riven to a narrow horizon of finitude, in which the best one can imagine is more family and less greed." (Kinkle \& Toscano 2011: 45) We could add that Gekko is forgiven thanks to his investing Winnie's money in a fusion research project seeking a way of creating clean energy. Does this mean that the end justifies the means? 
Figure 1: A family crisis with a happy ending (Shia LaBeouf and Carey Mulligan) in Wall Street: Money Never Sleeps by Oliver Stone.

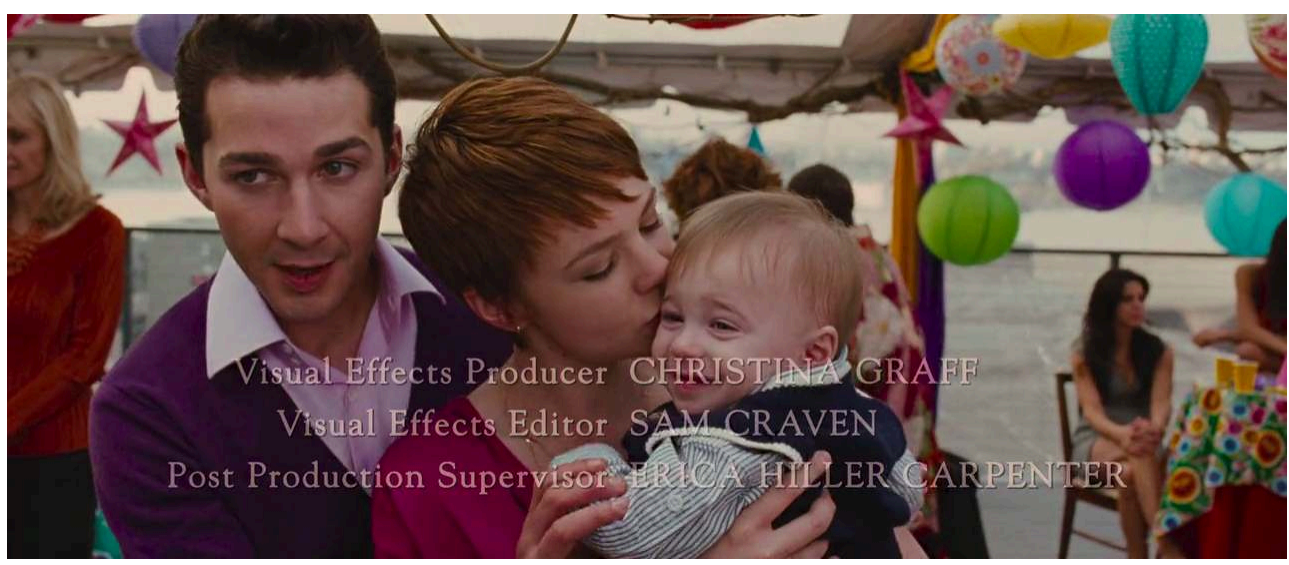

Source: Wall Street: Money Never Sleeps by Oliver Stone (screen capture).

Finally, what status should we attribute to the comments made as a voice-over at the beginning of the film?

You want to know what the mother of all bubbles was? It came out of nowhere. By chance. They called it the Cambrian Explosion. It happened around 530 million years ago. And over the next 70, 80 million years, the rate of evolution accelerated so fast that we came along. The human race.

The end of this cosmological metaphor is brought to its full at the end of the film:

Bubbles are evolutionary. They kill excess. They lean out the herd. But they never die. They just come back in different forms. When they burst, they give birth to a new day. Always creating change.

Such a conclusion seems to suggest that crises are a necessary evil because, ultimately, they are part of a natural systole and diastole at the heart of life.

\section{Margin Call}

Margin Call offers a clear-cut example of greed and financial malpractice within the walls of one bank building. Viewers follow young risk analyst Peter Sullivan as he travels up the hierarchy ladder, meeting successively all the executives of the firm. At the top of the building, CEO John Tuld lands his helicopter and makes an entrance reminiscent of that of a video-game boss. Sitting alone at the table of the building's restaurant (Figure 2), he peacefully sips on fine wine and savors sophisticated food while conferring on the necessary return of crises. 
Figure 2: CEO John Tuld (Jeremy Irons) in his ivory tower in Margin Call by J. C. Chandor.

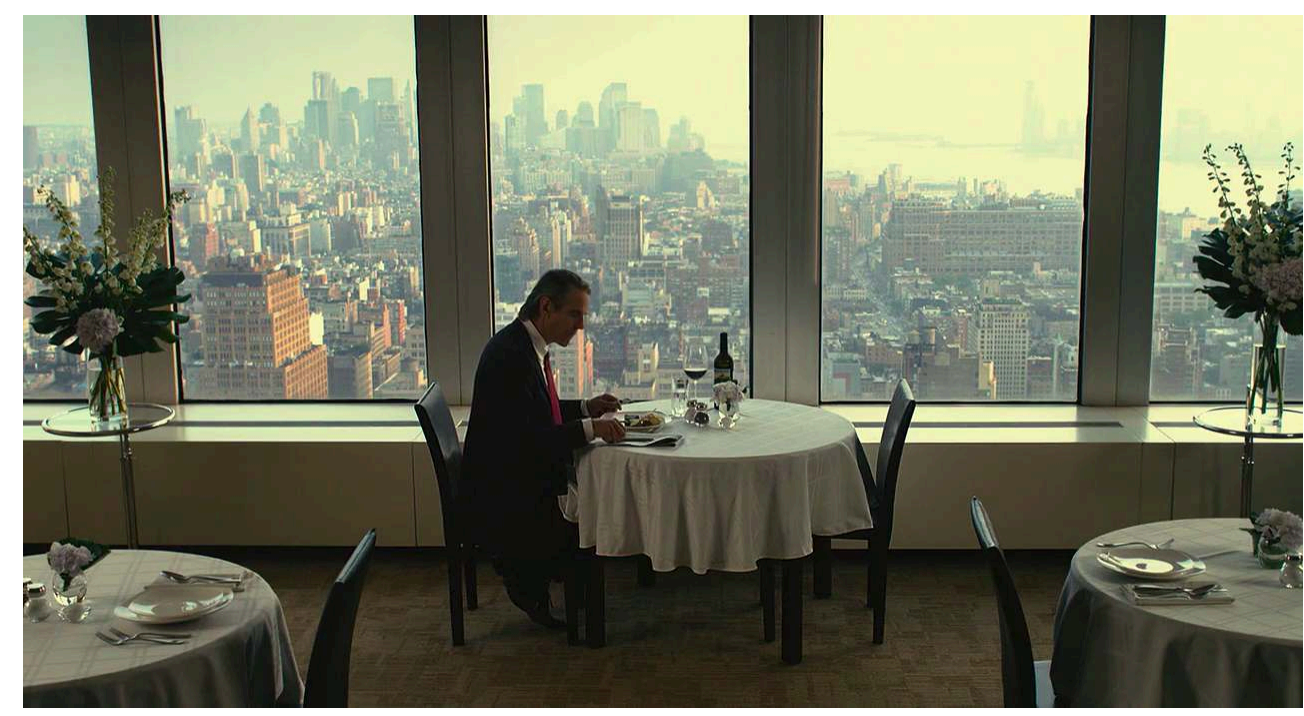

Source: Margin Call by J. C. Chandor (screen capture).

34 The difference with Oliver Stone's film is that a moral counterpoint is brought to the fore with two characters, Sullivan and Sam Rogers (Kevin Spacey), who repeatedly point at the consequences of the CEO's strategy. Their reservations add dialogism to the film, which testifies to director J. C. Chandor's clear condemnation of financial malfeasance.

However, their scruples do not lead them to take any serious action. At the end of the film, Sam Rogers laments the death of his dog like the death of his illusions about the financial world, yet his misgivings did not prevent him from participating in Tuld's scheme and accepting his share of the loot. The formal beauty of the film, with its sleek blueish tones, its processions of elegant suits, and its grandiose shots of the New York skyline, provides the bank building with an Olympian aura from which average people in the street look insignificant.

Chandor's decision to concentrate the plot over a 24-hour period in a single location, with the growing time pressure, the vain efforts of human beings threatened with disaster, their resignation in the face of an all-powerful impersonal force, and the perception of their impotence confer to this film the features of a modern tragedy. In sum, the film is compelling in exposing the extent of bankers' greed but it does not really equip the audience with a deeper understanding of what led to the crisis, nor does it seem to believe in any possible solution.

\section{Too Big To Fail}

Based on real facts, Curtis Hanson's Too Big To Fail is a political thriller which conveys a sense of emergency. The plot begins with the sale of the troubled investment bank Bear Sterns to JP Morgan, a sale guaranteed by the federal government. A fast pace is kept as Henry Paulson progressively faces an epic accumulation of situations similar to that of Bear Sterns: Lehman Brothers, Merrill Lynch, and AIG all collapse. His attempts at having the banks fix the situation among themselves fail because of greed and petty rivalries of their CEOs, as demonstrated by their private phone calls. The bailout is presented to Paulson in the second half of the film as a solution of last resort, to which 
he reluctantly agrees. In a scene, his staff make a swift mental calculation to evaluate the amount of money needed to save the economy. The figures with which the viewer is bombarded are so extravagant that when they are magically downgraded to $\$ 7$ billion, one cannot but share Paulson's reaction as he says: "It's better than a trillion." He and Ben Bernanke then proceed to lobbying the Congress to approve the bailout.

The two protagonists come out as heroic. Bernanke, who had just confessed to Paulson how deeply panicked he was before walking into the meeting room, impresses the viewer by keeping his composure as he faces outraged representatives and obdurate CEOs. His speech to the major banks appears as a criticism of their greed and selfishness; he presents the bailout as a "bold" action, necessary to protect the people. The soundtrack, featuring strings playing adagio, adds weight to his words. Paulson is also portrayed in a sympathetic light: a simple man in a simple home, walking in his pajamas while subject to insomnia. His courage is emphasized by his capacity to control an anxiety that only takes over when he is left alone (Figure 3).

Figure 3: A decent man dedicated to his country: Henry Paulson (William Hurt) in Too Big To Fail, by Curtis Hanson.

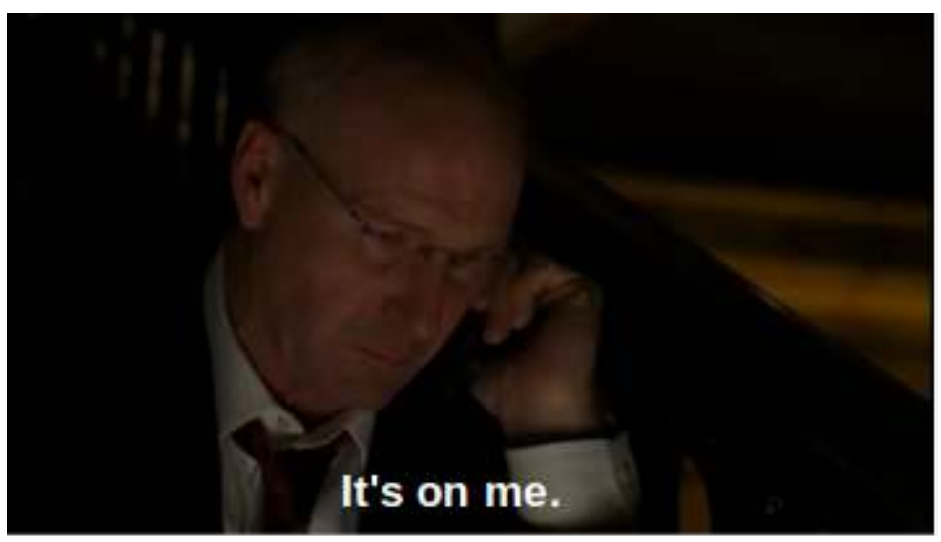

Source: Too Big To Fail, by Curtis Hanson (screen capture).

The film does not leave much room to reflect on the causes of the crisis. "How is it possible you didn't see it coming?” House Speaker Nancy Pelosi (Linda Glick) asks, to which Paulson replies: "If you want to rewind the tape, you can do that, but right now the one thing we don't have is time." Too Big to Fail turns out as an unmitigated eulogy for two highly controversial decision-makers, but their tight bonds with Wall Street and responsibility in deregulating finance remain unaddressed.

\section{The Big Short}

The scope embraced by The Big Short (2015) is considerably wider than that of the three previous productions. Tying together three storylines, the narrative manages to examine various professions in the banking business. We follow Mark Baum (Steve Carell) in his discovery of the securitization food-chain, the role of mortgage companies, money lenders, and rating agencies. Director Adam McKay was also successful in using some codes of the documentary, with Jared Vennett (Ryan Gosling) breaking the fourth wall and inserted interviews designed to provide technical elucidations. Vennett insists on the ideological importance of such digressions, no matter how clumsily they are incorporated into the plotline: 
Mortgage-backed securities, subprime loans, tranches - it's pretty confusing, right? Does it make you feel bored? Or stupid? Well, it's supposed to. Wall Street loves to use confusing terms to make you think only they can do what they do. Or even better, for you to just leave them the fuck alone.

The impact of government policies and regulation is left aside but the upbeat montage, simultaneous plots, humorous tone of the narrative voice, derisive exposure of complex financial derivatives as a scam to deceive lay people, all combine to make the financial world both accessible and entertaining. However, this appeal and excitement are probably also what makes this film problematic. The prestigious cast pulls the film toward bank-robbery movies, a genre of which Brad Pitt is a familiar figure (Pitt plays Ben Rickert, a legendary retired securities trader). The recurrent statement that these men had the intelligence of foreseeing the general meltdown before anyone else which is inaccurate, for there had been clear red flags about the financial situation from 2005 onwards - contributes to presenting them as heroes and contributes to producing yet another Gekko effect (Figure 4).

McKay made his critical point clear in the epilogue sequence, concluding on the uselessness of the bailout and ongoing creation of other derivatives under novel obscure terminology. Mark Baum and Ben Rickert, who endorse a moral stance and display disgust at the numerous aberrations of the financial system as a whole, do not undertake any action against it.

Figure 4: A passive moral figure (Brad Pitt as Ben Rickert facing two hapless characters) in The Big Short, by Adam McKay.

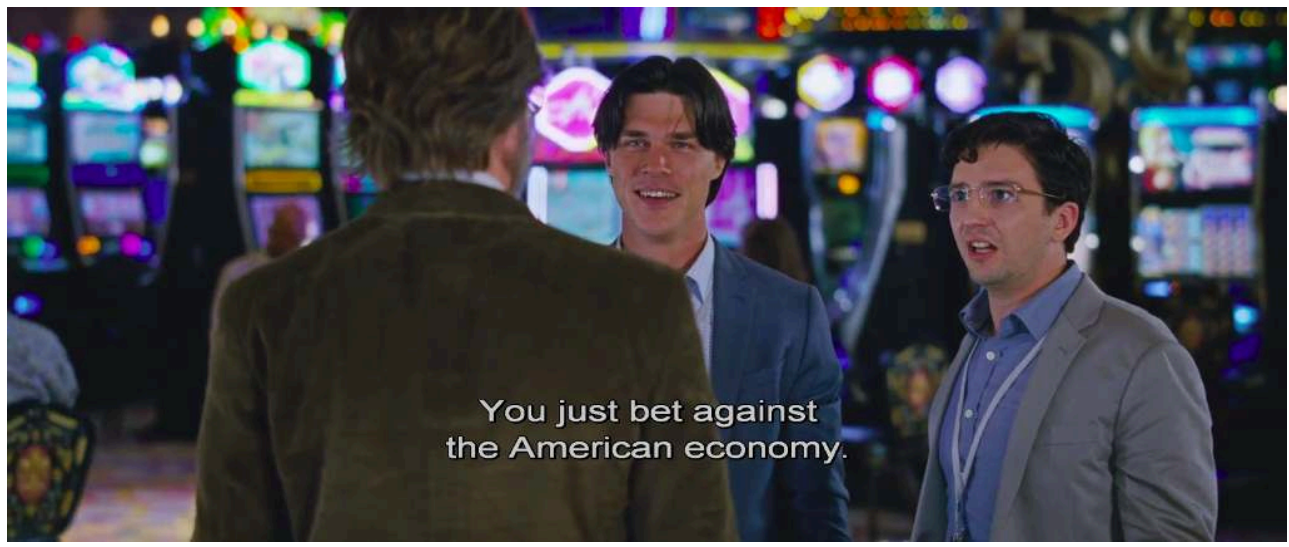

Source: The Big Short, by Adam McKay (screen capture).

Baum decides to keep quiet, while Rickert is presented as a visionary who has already started to invest in seeds, anticipating their shortage in the very-long term. Overall, McKay's film limits itself to criticizing the status quo and runs the risk of upholding an idealized image of traders.

\section{Overdose}

Moving on to documentaries, which are on the whole more critical than the fictions of our corpus, we begin with Overdose, whose argument relies largely on two spun metaphors: the punch bowl and the drug injection to a "patient." Both intend to establish that nationalizations and bailouts offer a quick fix that, in the long run, provides fuel for more bubbles. The documentary also makes extensive use of simple 
graphics in black, white and red colors (Figure 5), loud dramatic music, and a script narrated by a deep voice-over reminiscent of that used in action film trailers. Favoring sensationalism and effective visuals, the film is especially designed to scare the audience with its doomsday rhetoric.

Figure 5: The upcoming death of the patient in Overdose, the Next Financial Crisis by Martin Borgs.

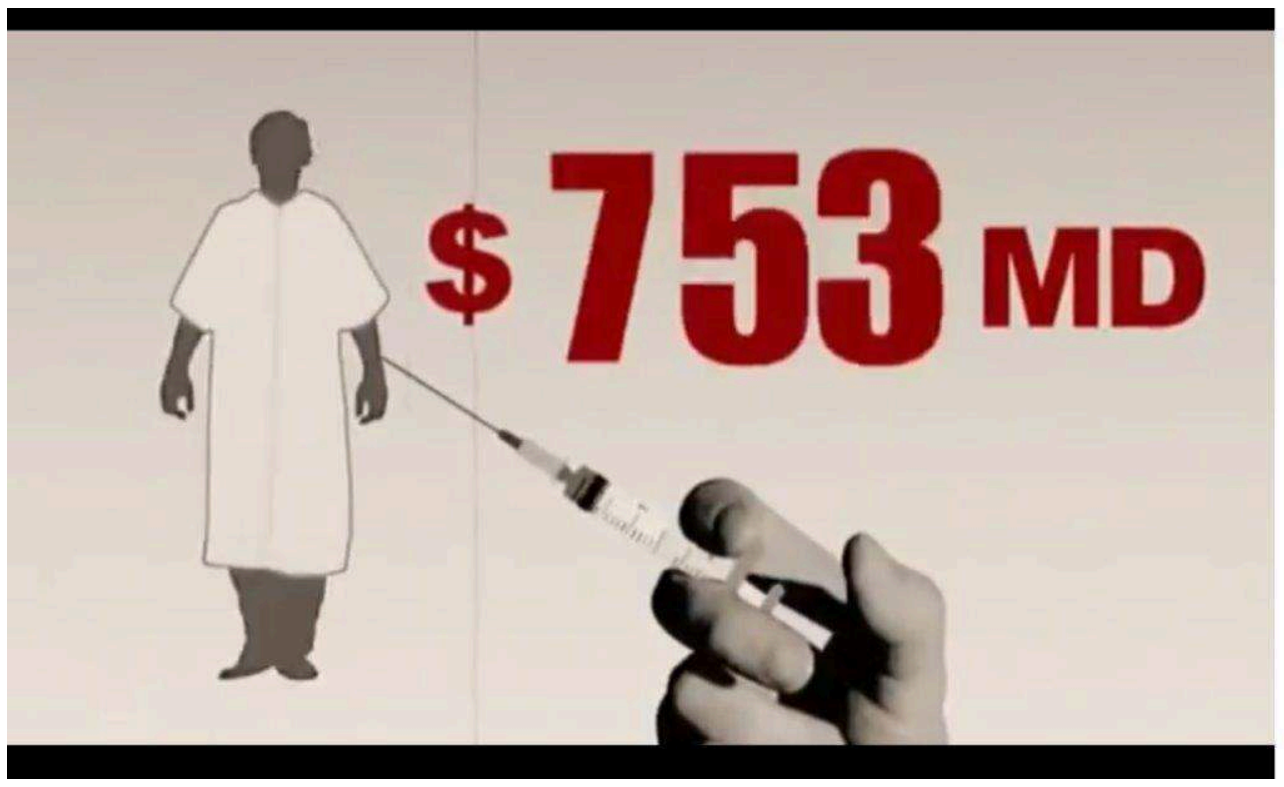

Source: Overdose, the Next Financial Crisis by Martin Borgs (screen capture).

What matters most is that the film is based on Financial Fiasco, a book written by Johan Norberg, who co-authored the screenplay with Martin Borgs. Norberg is a senior member of the Cato Institute, a libertarian thinktank, which also produced the film. The film's argument is clearly an indictment of state interventionism. Borgs and Norberg address at length the role played by Fannie Mae and Freddie Mac, arguing that state-backed mortgages "allowed lenders to go crazy." According to Norberg, had the private sector been in charge of securing mortgages, toxic assets would never have existed in the first place. The "highest bailout in history" is ultimately the film's main target. Norberg and Borgs denounce the absurdity of offering taxpayer money to banks without any strings attached, adding that "even banks who don't want the money will be forced to take it." Whilst Curtis Hanson tried to minimize the amount of money spent by the federal government, Norberg's calculation brings him to take other expenses into consideration: other bailouts, the lowering of interest rates, and much more, which allows him to say that the total expenses made by the federal government exceeded the combined cost of the two world wars, the Marshall Plan, and other conflicts. One could argue, however, that it is intellectually dishonest to include state funding directed at the car industry and expenses for social care under the Obama administration in the total cost of the bailout. The film condemns any form of state interventionism, grounding its criticism in the belief that the market will naturally regulate itself. 


\section{Capitalism: A Love Story}

At the other end of the political spectrum stands Capitalism: A Love Story. Michael Moore's film presents the long-term evolutions of capitalism and argues that it is the quest for profit which is responsible for the crisis. Taking average American families impacted by the financial crunch as a starting point, the filmmaker explores the economic system from the bottom up, and vilifies money lenders, mortgage companies, and the collusion between Wall Street and the government. Moore's originality rests upon his condemnation of capitalism as a whole. He is the only director in the corpus who interviewed Christian priests condemning capitalism as "evil" and against the teachings of Jesus. A montage displays a large crucifix superimposed on a shot of the stock exchange. The end of the film seeks to promote "socialism" with an interview of Bernie Sanders, and celebrates Franklin D. Roosevelt, who intended to include a second Bill of Rights in the Constitution guaranteeing the rights to work, to have a decent home and economic protection, as well as the rights to access medical care and good education.

Figure 6: Families broken by the crash in Capitalism, $A$ Love Story by Michael Moore.
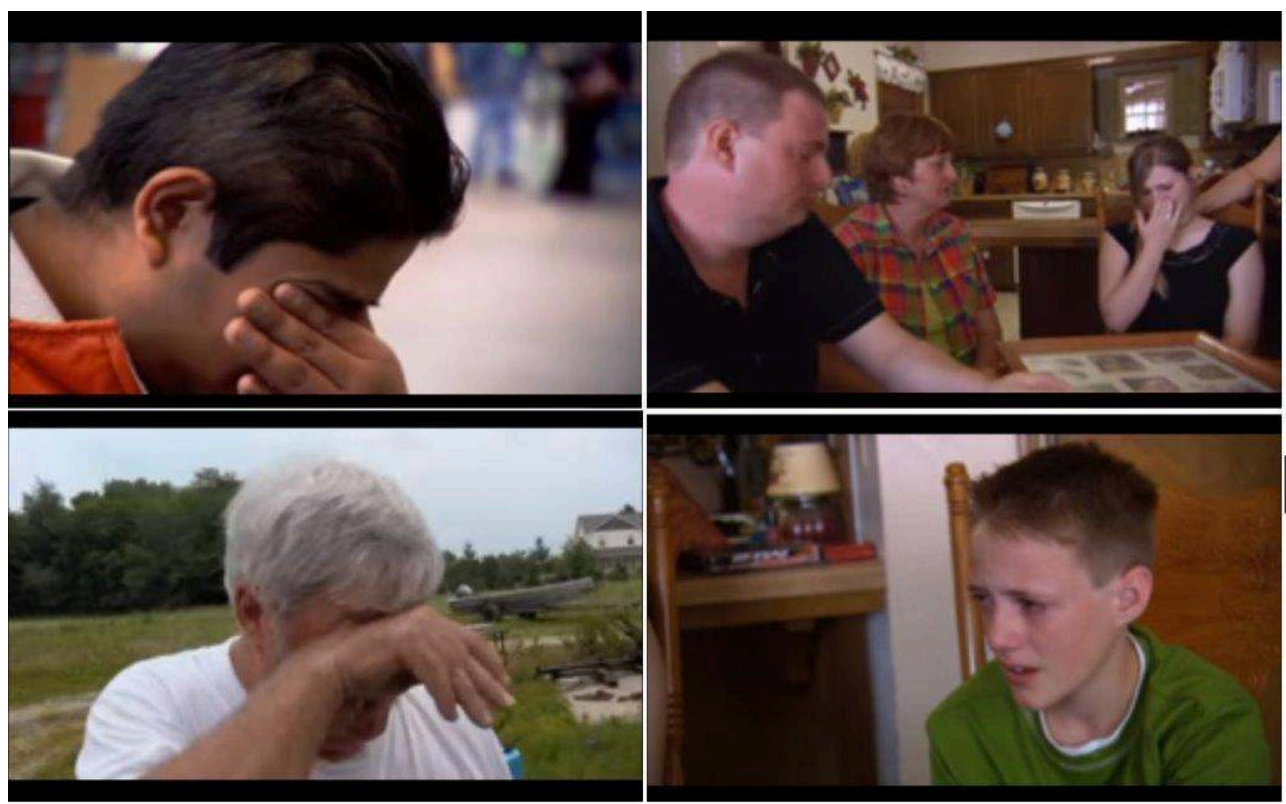

Source: Capitalism, A Love Story by Michael Moore (screen captures).

As far as means of action are concerned, Moore gives a list of successful demonstrations, strikes, and sit-ins, and pays particular attention to the Flint strike against General Motors in 1936, a significant victory for trade unionism. Yet, Moore also stages himself haranguing random busy bankers walking out of their offices in Wall Street. He turns up in front of bank headquarters with a robbery bag, asking them to give back the "money of the American people". Finally, he uses a megaphone pretending to arrest bankers. Such scenes may seem rather trivial and show that, despite the rich material featured in his documentary, Moore does not really engage in a rational debate but rather seeks to trigger a visceral response among viewers. His arguments may at times look vague: for instance, he correlates the rise of bankers' bonuses with the rise of sales in antidepressants. Similarly, after underlining the 
pressure under which Congress adopted the motion to bailout Lehman Brothers, Moore interviews Representative Marcy Kaptur. He asks her whether she would agree to call the bailout "a financial coup d'état." After some hesitation, the Democratic representative finally agrees that "Wall Street" really is in charge of political affairs. The filmmaker also relishes filming devastated families and anxious workers, filming their distressed faces in close-ups, pressing them with questions until they start crying (Figure 6). Finally, Moore's tone is generally sarcastic and, thanks to fast cutting, he equates the actions of those he calls "the rich" with racketeering and pickpocketing.

\section{Inside Job}

By contrast, the tone of Inside Job is serious. Matt Damon's commentary is uttered in a calm, professorial voice. Like Moore, Ferguson makes extensive use of fast cutting. Yet, while Moore used inserts to ridicule the rich, Ferguson provides rigorous research and fact-checking. Without trying to avoid didacticism, the documentary describes the intricacies of the political and financial spheres with a wealth of detail. It also points at strategic errors made by Paulson in 2008, blames politicians for their suspicious lack of reactions ahead of the crisis since - Ferguson insists on this - there had been numerous red flags as early as 2005.

Ferguson gives a better insight than previous films into the global dimension of the crisis. The case of Iceland is explained in detail and the filmmaker shows the repercussions of the crisis in China and Singapore. Among the causes of the crisis, Ferguson also includes the pathological behavior of high-class financiers. Their regular use of drugs and prostitutes is exposed in order to illustrate how these white-collar criminals place themselves above the law. Fraud and money-laundering, involvement in arm dealings are also mentioned. Finally, Ferguson demonstrates his originality when denouncing the role played by academics and experts in helping to guarantee toxic products and unreasonable investments (Figure 7).

Figure 7: Charles Ferguson challenges an angry academic in Inside Job, by Charles Ferguson.

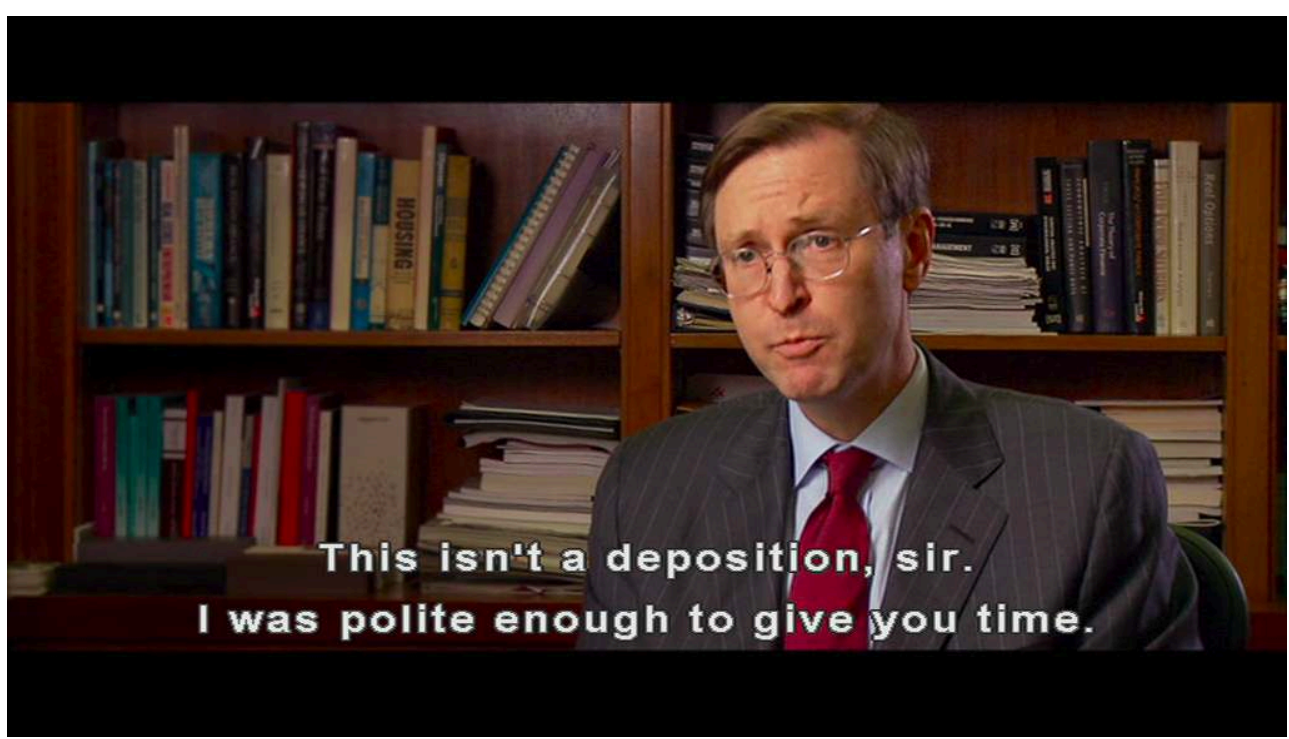

Source: Inside Job, by Charles Ferguson (screen capture) 
options are offered by this documentary. The priority is given to fighting the extremely powerful lobbies and the subsequent hold that banks have on governments. Choosing Matt Damon, a celebrity known for supporting Obama's campaign, is also a way of expressing disappointment toward an administration that did not manage to free itself from the influence of Wall Street. With regard to experts, Ferguson suggests that a form of regulation of academic publications should be implemented to avoid conflicts of interests. Finally, he even implies the possibility of punishing perpetrators of fraudulent financial moves by convicting them of other crimes principally related to use of drugs and prostitutes.

\section{Global Financial Meltdown}

Global Financial Meltdown (2010) is the most thorough film of the corpus. It presents the same causes of the economic crunch as the other documentaries but digs deeper. Terrence McKenna, the director, insists on the international dimension of the whole phenomenon more than other filmmakers. He addresses the role played by European countries, recalling the deregulation measures encouraged by Gordon Brown, then British Chancellor of the Exchequer, in an attempt to turn the City into the foremost financial market. Episode 3, entitled "Paying the price," provides abundant footage of strikes in France (Figure 8), during which the workers of Continental and Caterpillar kidnapped their bosses to force them to negotiate with strikers. Demonstrations in front of Iceland's Parliament are also displayed.

Figure 8: "Les Contis": Local effects of a global crisis in Global Financial Meltdown by Terrence McKenna.

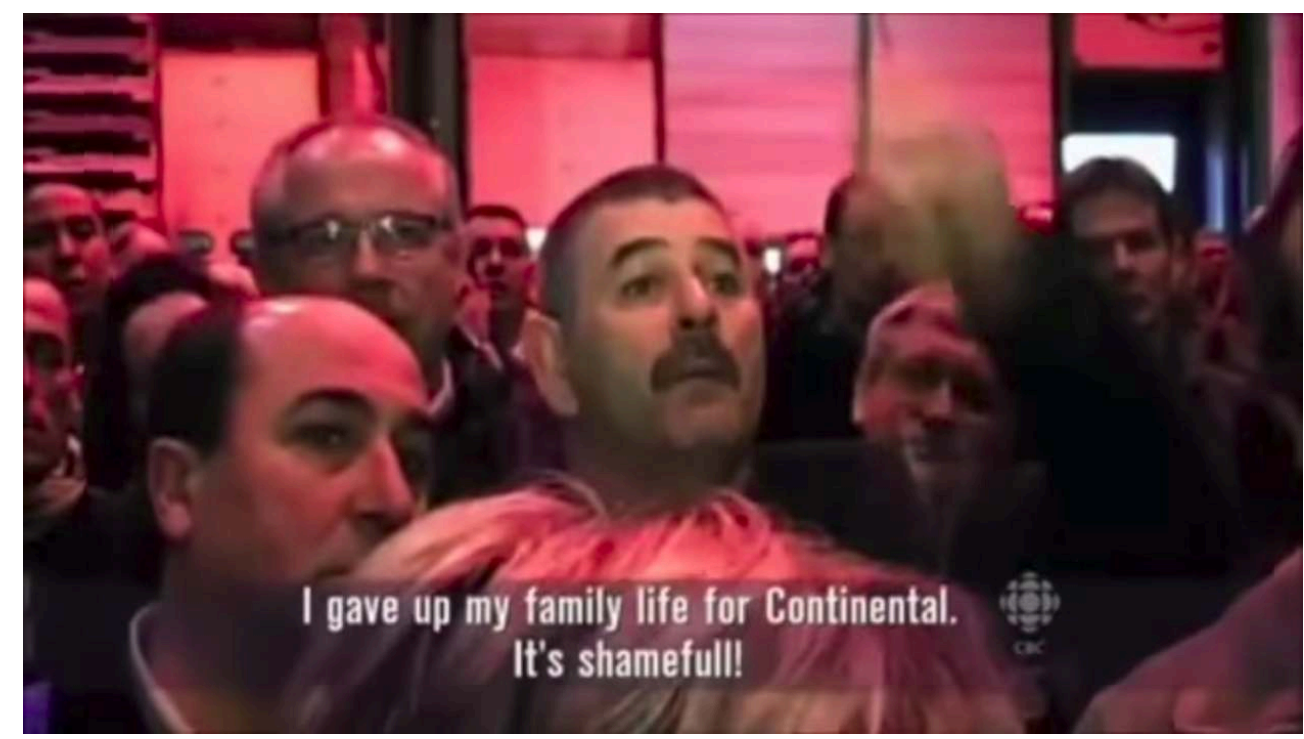

Source: Global Financial Meltdown by Terrence McKenna (screen capture).

The main risk run by the film is to confuse the viewer with its formidable mass of information. The film turns out to perhaps too rich and dense. One may also be skeptical about the excessive optimism of the director when he closes this four-part film with the idea that politicians and IMF leaders have now understood the necessity of urgently legislating to regulate finance. As for the final vision of workers walking 
cheerfully in the blazing sunlight, strangely reminiscent of social-realistic propaganda posters, one wonders if this is it to be interpreted as a threat to the neoliberal order.

\section{Conclusion}

8 films that have been studied share defining elements of the sub-genre formed by post-2008 movies, from visual elements such as the omnipresence of figures, plunging graphs and skyscrapers, to the obligatory need to popularize financial jargon. Given the complexity of present-day financial markets, a certain amount of didactics is needed in cultural productions targeting a wide audience. Surely this informative and explanatory dimension played a key role in attracting viewers. Fictions, with their brilliant casts and alluring dramatization, did well at making a rather dry topic both accessible and visually attractive, with the risk of glamorizing a topic of both ethical and ideological importance. Documentaries, on their part, offered a much more critical view, especially when they addressed the crisis as a worldwide phenomenon revealing the shortcomings of neoliberalism, and when they displayed popular dissent directed at capitalism.

It is worth stepping back and look at the context in which these films were created and first seen. Most were released within the two years following the 2008 crisis. The economic crisis as a historical event had been immediately turned into a popular cultural product. Replacing the production of films upholding a strong anti-capitalist narrative in their context of production, Ribstein (2009) published an article with the provocative title: "How movies created the financial crisis." The author emphasized the fact that filmmakers are embedded in the capitalist system, and that the film industry is unlikely to bite the hand that feeds it. Therefore, bankers appear as the sensible guilty party. Blaming them satisfies the audience's thirst for explanation and blame, without pointing at other structural dynamics, such as deregulation policy or states bailing out banks with taxpayer money. Such an analysis is quite pessimistic as to the critical role that mass-cultural productions can play within neoliberalism. Nevertheless, our investigation has shown that post-2008 films have contributed to circulating a diversity of views on the crisis, revealing the extent of the social catastrophe it has caused, making its mechanisms accessible to a lay audience, and, occasionally, picturing means of resistance. Whether such a rapid codification of the historical crisis into a product of mass-consumption contributes to higher political awareness or undermines its very possibility remains open.

\section{BIBLIOGRAPHY}




\section{Books and articles}

Castree, Noel. "The 2007-09 financial crisis: narrating and politicising a calamity." Human Geography: a new radical journal 3 (1) 2010: 34-48.

Corliss, Richard. “Wall Street: Money Never Sleeps: Gekko and Greed Are Back.” Time: 4 May 2010.

Gamble, Andrew. “Neo-liberalism.” Capital \& Class 25 (3) 2001: 127-34.

Genette, Gérard. Figures III. Paris: Seuil, 1972.

Hall, Stuart and Doreen Massey. "Interpreting the crisis." Soundings (44) 2010: 57-71.

Harvey, David. A Brief History of Neoliberalism. Oxford: Oxford UP, 2005.

Hay, Colin. "The 'crisis' of Keynesianism and the rise of neoliberalism in Britain: an ideational institutionalist approach.” In John L. Campbell and Ove K. Petersen (ed.). The Rise of Neoliberalism and Institutional Analysis. Princeton, NJ: Princeton UP, 2001: 193-218.

Jessop, Bob. "Critical semiotic analysis and cultural political economy." Critical Discourse Studies 1 (2) 2004: 159-74.

Jessop, Bob. "Cultural political economy and critical policy studies." Critical Policy Studies 3 (3-4) 2010: 336-56.

Kinkle, Jeff and Alberto Toscano. "Filming the Crisis: A Survey." Film Quarterly 65 (1) 2011: 39-51. Ribstein, Larry E. "How movies created the financial crisis." Michigan State Law Review 2009: 1171-89.

\section{Filmography}

Capitalism, A Love Story (2009), by Michael Moore. 127mn. Prod. Dog Eat Dog Films and The Weinstein Company. Distr. Overture Films.

Global Financial Meltdown (2010), by Terence McKenna. 60mn x 4 episodes. CBC.

Inside Job (2010), by Charles Ferguson. 108mn. Sony Pictures Classics. Narrated by Matt Damon.

Margin Call (2011), by J. C. Chandor. 109mn. Lionsgate. Feat. Kevin Spacey, Paul Bettany, Jeremy Irons, Zachary Quinto, Simon Baker, Demi Moore, Stanley Tucci, et al.

Overdose, the Next Financial Crisis (2010), by Martin Borgs. 46mn. Cato Institute. Narrated by Johan Norberg.

The Big Short (2015), by Adam McKay. 130mn. Paramount. Feat. Christian Bale, Steve Carell, Ryan Gosling, Brad Pitt, et al.

The Girlfriend Experience (2009), by Steven Soderbergh. 77mn. Magnolia Pictures. Feat. Sasha Grey et al.

The Other Guys (2010), by Adam McKay. 107mn. Columbia Pictures. Feat. Will Ferrell, Mark Whalberg, Eva Mendes et al.

Too Big to Fail (2011), by Curtis Hanson. 98mn. HBO. Feat. William Hurt, Edward Asner, Billy Crudup, Paul Giamatti, Topher Grace, Cynthia Nixon, et al.

Up in the Air (2009), by Jason Reitman. 109mn. Paramount. Feat. George Clooney et al. 
Wall Street: Money Never Sleeps (2010), directed by Oliver Stone. 133mn. $20^{\text {th }}$ Century Fox. Feat. Michael Douglas, Shia LaBeouf, Josh Brolin, Carey Mulligan, Eli Wallach, Susan Sarandon, Frank Langella, et al.

\section{ABSTRACTS}

The 2008 crisis has been represented in many fiction and documentary films. This paper analyses these representations in order to present the aesthetic and political characteristics of widely circulated narratives of the crisis. This paper analyses 8 films, starting with an overview, then a structural comparison of these films, isolating the common features of this sub-genre in terms of tropes, characterization and narrative strategy. The paper then assesses the films' critical dimension against the complexity of their depiction of the 2008 neoliberal crisis and the space granted to anticapitalist voices. Both fictions and documentaries reveal a didactic dimension, but they differ as to their critical dimension. Fictions, with their brilliant casts and alluring dramatization, did well at making a dry topic both accessible and visually attractive, with the risk of glamorizing a topic of both ethical and ideological importance. Documentaries offer a much more critical view, especially when they address the crisis as a worldwide phenomenon revealing the shortcomings of neoliberalism, and when they display popular dissent directed at capitalism. These films armed their viewers with technical knowledge about finance, but for the most part did not encourage viewers to question capitalism as such.

La crise financière de 2008 a inspiré beaucoup de documentaires et de films de fiction. Cet article étudie les caractéristiques esthétiques et politiques des interprétations de la crise véhiculées par 8 films, et commence par en proposer un résumé avant d'en comparer la structure pour dégager les traits typiques de ce «sous-genre » en termes de figures, de construction des personnages et de stratégie narrative. La dimension critique de ces films est ensuite évaluée à l'aune de la complexité de la représentation qu'ils offrent de la crise du capitalisme néolibéral et de la place accordée aux opinions anticapitalistes. Il apparaît que les fictions, comme les documentaires, ont une importante dimension didactique, mais sans avoir la même portée critique. Les fictions du corpus se distinguent par des distributions prestigieuses et une tendance à l'idéalisation qui font courir le risque de faire oublier l'importance éthique et idéologique du sujet au profit de l'esthétisme ou du divertissement. Les documentaires proposent des lectures bien plus critiques de la crise, notamment lorsqu'ils en soulignent les dimensions mondiales et représentent divers types de contestation anticapitaliste. Dans leur majorité, ces films aident le public à mieux comprendre le fonctionnement de la finance mais rares sont ceux qui remettent en cause l'existence du système néolibéral en tant que tel.

\section{INDEX}

Keywords: financial crisis, capitalism, neoliberalism, representation, fiction film, documentary, film

Mots-clés: crise financière, capitalisme, néolibéralisme, représentation, film de fiction, documentaire, cinéma 


\section{AUTHORS}

\section{JULIETTE FEYEL}

Juliette Feyel holds a PhD in comparative literature from the University of Paris Nanterre. Her research deals with the politics of gender and body representations in erotic literature, cinema and graphic novels. Contact: juliette.feyel [at) gmail.com

\section{CLÉMENCE FOURTON}

Clémence Fourton holds a PhD in British Studies from the University of Poitiers. Her research focuses on the social and political effects of the 2008 crisis in the UK. She is a graduate of the École normale supérieure de Lyon. Contact: clemence.fourton [at) gmail.com 